\title{
MUNDO RURAL
}

\section{LUCIANA HEYMANN, MARCO AURÉLIO VANNUCCHI \\ E PAUlO FONTES}

EDITORES

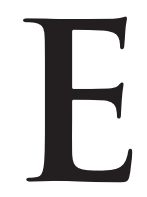

ste número de Estudos Históricos consagra-se à temática do mundo rural. Os artigos destacam o processo histórico brasileiro, ainda que a realidade paraguaia seja examinada por um dos textos publicados.

Pode-se dizer que a História e as Ciências Sociais surgiram no país tomando o mundo rural como um de seus objetos centrais. Lugar no qual viveu a maioria da população brasileira na maior parte da história, o campo converteu-se em tema de reflexão acadêmica associado ao atraso. Suas supostas expressões religiosas (como o messianismo), formas políticas (como o coronelismo) e conformação econômica (guardando semelhanças com o feudalismo) atestavam o arcaísmo que intelectuais de variadas colorações ideológicas desejavam fosse superado como condição para o desenvolvimento do Brasil. Ao longo do tempo, essa perspectiva foi se atenuando, abrindo espaço para a análise de fenômenos recentes, compreendidos não necessariamente na chave do atraso, tais como a consolidação de movimentos sociais vigorosos e de um capitalismo sustentado pelo agronegócio. 0 presente número de Estudos Históricos pretende contribuir para o esforço de uma compreensão matizada e mais abrangente do mundo rural, sem deixar, contudo, de jogar luz sobre suas mazelas e contradições.

0 primeiro artigo, "Transformações na legislação sesmarial, processos de demarcação e manutenção de privilégios nas terras das Capitanias do Norte do Estado do Brasil", analisa as vicissitudes do instituto da sesmaria na colônia, especificamente, entre fins do século XVII até meados do seguinte.

Luciana Heymann, Marco Aurélio Vannucchi e Paulo Fontes são professores da Escola de Ciências Sociais da Fundação Getulio Vargas (CPDOC/FGV). 
O segundo artigo, "O colonato na região serrana fluminense: conflitos rurais, direitos e resistências cotidianas", acompanha o desenvolvimento desse regime de trabalho na cafeicultura e seu impacto sobre os trabalhadores a ele submetidos. "Quem é mais útil ao país: aquele que planta ou o que fica na cidade só comendo?: os trabalhadores rurais fluminenses e a luta por desapropriação de terras (1962-1963)", debruça-se igualmente sobre o mundo do trabalho no campo, ao examinar a mobilização de posseiros de Magé (Rio de Janeiro). Os trabalhadores rurais, mais particularmente os canavieiros, também são estudados em "Cultura, política e direitos no canavial da ditadura militar brasileira".

Por sua vez, em "O pobre solo do celeiro do mundo: desenvolvimento florestal e combate à fome na Amazônia", a problemática tratada é a atuação de duas agências internacionais, a UNICEF e a FAO, na Amazônia nos anos 1950 e 1960. "As transformações socioambientais da paisagem rural a partir de um desastre ambiental (Paraná, 1963)" concentra-se num incêndio de grandes proporç̧ões ocorrido em 1963 para refletir sobre as mudanças experimentadas pela paisagem rural paranaense no período.

0 artigo "Estado e mercado na reforma agrária brasileira (1988-2002)" tem como tema a política de reforma agrária no período posterior à promulgação da atual Constituição, privilegiando a interação entre Estado e mercado na elaboração dessa política. Finalmente, "Capitalismo agrário e os movimentos campesinos no Paraguai" analisa a formação e o desenvolvimento de uma economia agrária nesse país baseada na grande propriedade e voltada ao mercado externo, a partir da ditadura Stroessner.

http://dx.doi.org/10.1590/S0103-21862015000200001 